\title{
Baixio das bestas e Árido movie: entre a "podridão do mundo" e as perspectivas de mudanças
}

///////////////// Marcelo Dídimo Souza Vieira ${ }^{1}$

Érico Oliveira de Araújo Lima

1. Professor-adjunto do Programa de Pós-Graduação em Comunicação da Universidade Federal do Ceará. E-mail: mdidimo@hotmail.com

2. Mestrando do Programa de Pós-Graduação em Comunicação da Universidade Federal do Ceará. E-mail: ericooal@gmail.com 


\section{Resumo}

A constituição de um pensamento imagético a partir do Nordeste brasileiro move reflexões no campo da estética cinematográfica que envolvem as potências de produzir questões a respeito de um mundo. Conceber uma imagem do universo nordestino é criar um olhar, formular problemas sobre as possíveis visualidades desse espaço. Esse processo dá-se em meio a temporalidades múltiplas, na constituição de imagens contemporâneas. A produção cinematográfica recente de Pernambuco conjuga questões sobre sua espacialidade e visualidade, imagens de um Nordeste em tensão com problemáticas políticas. Neste artigo, procura-se discutir as forças organizadas pelos filmes Árido movie (Lírio Ferreira, 2005) e Baixio das bestas (Cláudio Assis, 2007), que se colocam diante dos desafios de reinventar imagens para o Sertão nordestino.

\section{Palavras-chave}

Cinema, história, Nordeste, política.

\section{Abstract}

The constitution of a imagery thought from Brazilian Northeast takes place of a reflection in the field of cinema aesthetics, involving the powers to produce questions about its own world. Designing an image of the universe consists in creating a look of the Northeast, conceibing possible problems of the visualities at this space. This process occurs in multiple temporalities, in a way that constitutes contemporary images. The recent film production of Pernambuco combines questions about this space and visuality, images of a Northeast in tension with political problems. This paper seeks to discuss the forces organized by Árido movie (Lírio Ferreira, 2005) and Baixio das bestas (Claudio Assis, 2007), to face the challenges of reinventing images to the Northeast.

\section{Keywords}

Cinema, history, Brazilian Northeast, politics. 


\section{Introdução}

A constituição de um pensamento imagético a partir do Nordeste brasileiro move embates no campo da estética cinematográfica que envolvem as potências de produzir, no âmbito da materialidade fílmica, questões a respeito de um mundo. Conceber uma imagem do universo nordestino é inventar um olhar, formular problemas sobre as possíveis visualidades desse espaço: em diferentes épocas da história, a arte cinematográfica tentou constituir modos de ver a partir dessa região, tentou intervir, buscou aproximar-se, envolveuse em percursos tortuosos e em contradições, sempre no desafio de elaborar sensibilidades possíveis. E lançar um olhar é mais do que registrar um universo, é propor questões para o mundo, formular a composição da imagem como um problema. É preciso pensar sobre o que dizem as imagens contemporâneas do Nordeste, que potência de enunciar elas contêm. E essa busca não cessa de colocar em cena o passado, as tradições cinematográficas, numa relação com obras distintas e com problemas que se reconfiguram ao longo das temporalidades. Tratar de um espaço implica questões dinâmicas, um movimento que procura ver e interrogar, mostrar situações e deslocar sentidos. Neste artigo, buscamos discutir as forças organizadas pelos filmes Árido movie (Lírio Ferreira, 2005) e Baixio das bestas (Cláudio Assis, 2007), que se colocam diante dos desafios de inventar imagens para o Sertão nordestino. Reunidas aqui, as duas obras são analisadas em composição com os demais olhares lançados em outros momentos da história e são pensadas em conjunto numa tentativa de articular cruzamentos possíveis a 
partir de uma pesquisa mais ampla que desenvolvemos sobre o que propomos chamar novo cinema nordestino.

Baixio das bestas sugere novas abordagens de um Nordeste tipicamente idealizado como espaço de pureza e reconciliação da história. A afirmação de um mundo abjeto é marcante na operação construída por Assis em seu cinema. Desde Amarelo manga (2003), era possível identificar uma preocupação em abordar os espaços a partir da temática da sexualidade e da violência. A encenação estabelece o choque sexual entre os personagens e a estrutura narrativa pontua a deriva dos personagens, rendidos ao sistema opressor.

Essa abordagem temática de Assis tem aliado-se a uma estética com preocupações plásticas marcantes. A ideia de um mundo marcado pelo abjeto é feita de forma fluida, com iluminação bem estudada e cenografia preestabelecida. Devem-se problematizar as implicações que essa imagem plástica do abjeto tem no sentido político e no âmbito da reflexão sobre o estado das coisas. Insere-se aqui a reflexão sobre a expressão da perda de utopias no cinema e a construção de obras que já não apontam destinos certos, mas afirmam a incerteza diante da violência no mundo.

No percurso para analisar a invenção do sertão feita em Árido movie, considera-se relevante o contraste entre sertão e litoral, em torno do qual importantes obras do cinema brasileiro foram construídas. Interroga-se a relação que o filme em questão faz entre esses dois universos. A obra traz um protagonista típico da modernidade tardia, sujeito a influências culturais múltiplas que, num mundo globalizado, se confundem na constituição dos indivíduos. O pertencimento ao sertão e o laço familiar são questões com as quais Jonas, protagonista do filme, se depara. Deve-se considerar também o lugar que Árido movie destina a temas políticos que percorrem seu enredo: o uso político da água, o coronelismo moderno, o misticismo, as relações de poder. Temas caros aos cineastas do Cinema Novo, que enfrentaram dilemas, revisaram suas próprias posturas e lançaram propostas estéticas politicamente engajadas, preocupadas com a coletividade. A obra 
| Marcelo Dídimo Souza Vieira e Érico Oliveira de Araújo Lima

estabelece um diálogo com essa geração de cineastas, mas é preciso verificar sob qual perspectiva os temas políticos são trabalhados.

\section{Inventário de um mundo abjeto}

Em dado momento de Baixio das bestas (Cláudio Assis, 2007), um "cheiro estranho" incomoda o personagem Mário (João Ferreira), em diálogo com Maninho (Irandhir Santos). A câmera é posta no alto, pairando sobre as cabeças dos dois homens e colocando no centro do quadro o buraco cavado por Maninho - uma fossa, mas também uma possível cova, como a narrativa procura lembrar a todo o momento. Os personagens especulam de onde viria o odor que sentem. Sugere-se, por um instante, que seja da usina em funcionamento nas proximidades, mas a sentença de Mário, mestre de maracatu e figura com ar de experiência, soa definitiva e pesa no ar: "Isso é a podridão do mundo!".

A abjeção ronda as vidas da comunidade no Baixio, na zona da mata pernambucana, local que passa por transformações ligadas tanto a aspectos econômicos (a decadência das usinas de cana-deaçúcar), quanto a morais, reiterados nas falas e atos dos personagens. No filme, as imagens são construídas, estilisticamente, para pensar os lugares dos sujeitos e o estado das coisas, e a estrutura narrativa procura articular núcleos distintos de personagens, num inventário de um universo em convulsão. Os corpos são postos em choque, expostos, arranjados esteticamente na cena - a miseen-scène de Cláudio Assis procura estabelecer relações tanto dos indivíduos entre si quanto dos sujeitos com seu meio. Após a sentença de Mário sobre a podridão do mundo, segue-se com a cena de uma orgia no cinema controlado por Everardo (Matheus Nachtergaele): os jovens de classe média, vindos de Recife, divertem-se com as prostitutas do interior, esbaldam-se em sexo e impõem uma relação de poder no confronto sexual - mais do que uma relação sexual, a coreografia dos corpos traz uma performance de luta, de "violentação" - com os corpos femininos.

Há, em Baixio das bestas, a expressão de um mundo sórdido, onde uma espécie de patologia social cerca os personagens e 
estrutura suas ações dramáticas. Toda a abjeção contida no filme implica, também, um contexto de opressão, sobretudo dentro de uma perspectiva de violência contra a mulher e o corpo feminino. Boa parte dos personagens masculinos carrega uma marca de perversão: o avô Heitor (Everaldo Pontes), que expõe a própria neta, Auxiliadora (Mariah Teixeira), para caminhoneiros em um posto, o jovem Cícero (Caio Blat) e seus amigos, sobretudo Everardo.

O tratamento dado por Cláudio Assis a esse universo no interior nordestino relaciona-se com a postura do diretor em seu filme anterior, Amarelo manga (2003), que se desenrola no espaço fechado de uma pensão no Recife. Sexo, violência e abjeção já caminhavam juntos para construir as histórias e organizar a disposição dos personagens com o meio. Entre os filmes, há uma diferença parcial, como chamou a atenção Cléber Eduardo (2007). Amarelo manga segue por um caminho comum a filmes do cinema brasileiro recente, o de só observar os efeitos da organização social dos indivíduos, sem adentrar nas razões estruturais dos problemas mostrados. Nessa linha, Xavier (2000) já destacou contrastes de abordagem entre o cinema brasileiro a partir da Retomada e os filmes do Cinema Novo:

\footnotetext{
Pode-se dizer grosso modo que, em termos de postura geral diante dos dramas focalizados, vemos um cinema atento a mentalidades, condutas morais, mas pouco disposto a explorar conexões entre o nível de comportamento visível, trabalhado dramaticamente, e suas determinações sociais mais mediadas. Ao contrário dos anos 60 , quando o cinema se apressava em interligar ser social, economia e caráter (colocando no centro a questão da ideologia), a vontade agora é explorar mais os sujeitos no que têm de singular (XAVIER, 2000, p.104).
}

Baixio das bestas esboça possíveis relações entre o contexto social e a degradação na vida dos personagens. Sobretudo no prólogo em preto e branco, reflexão sobre o tempo que a tudo engole, sobre as mudanças e o fim de ciclos históricos, o do engenho e o da usina, há a tentativa de contextualizar o mundo retratado, detectar possíveis causas do que se verá ao longo do 
| Marcelo Dídimo Souza Vieira e Érico Oliveira de Araújo Lima

filme. Mas essa diferença entre as duas obras de Assis revelase apenas parcial, como pontua Eduardo, pois a relação entre conjuntura e experiência dos personagens apresenta-se, por indução, apenas no prólogo e em alguns diálogos, não havendo

\begin{abstract}
nenhuma demonstração dessa relação na dramaturgia e, mais uma vez como em Amarelo manga, será por meio do sexo e da violência que a estrutura social irá manifestar a sua linguagem: a da degradação da carne, menos pela prostituição tradicional, mais pela agressividade com que, na relação com putas ou virgens, os homens agem com os corpos femininos. (...) A soma dessas situações e desses personagens compõe um painel local, caracterizado pelo uso da força e do poder contra o corpo, como faziam os coronéis, latifundiários e senhores de engenho com seus escravos. Em suma, como se via em Amarelo manga, impera o imobilismo (EDUARDO, 2007).
\end{abstract}

A ideia de painel, trazida por Eduardo, ilustra bem a estrutura narrativa em Baixio das bestas. Há todo um conjunto de relações, que são articuladas pela intervenção da narrativa cinematográfica e postas em contato pela montagem, que alterna situações, desloca espaços e induz a percepção da simultaneidade de tempos. Para fazer um inventário do amplo universo que pretende traduzir em imagem, Cláudio Assis não conta particularmente uma história, mas flui sua câmera pelos lugares da zona da mata nordestina, entre o cinema onde ocorrem orgias e o posto onde Auxiliadora é exposta, entre as plantações de cana e as preparações para a apresentação do maracatu popular em Recife. A comunidade vista no filme é retratada a partir dessa lógica de panorama, no qual as transformações do contexto econômico de extração canavieira são pano de fundo para as microssituações vividas pelos personagens. A usina de cana e os trabalhadores nas plantações não estão integrados aos eventos no filme a partir de uma relação direta, são apenas postos na imagem, misturam-se à paisagem: a narrativa dá a ver a conjuntura do mundo abjeto, não estabelece a articulação das partes.

Uma organização narrativa por fragmentos conduz o filme de Cláudio Assis, numa lógica comum a certos filmes contemporâneos. 
Árido movie também estrutura-se em torno de núcleos, postos em contato para dar a ver uma imagem do sertão. Nesse caso, o foco era no deslocamento dos sujeitos e nas múltiplas referências culturais desencadeadas pelo contexto migratório típico de tempos de globalização. O próprio Amarelo manga, em um contexto urbano, organiza-se em fragmentos, em torno de moradores da periferia de Recife. O que se vê em Baixio das bestas é a fragmentação como meio para se dar conta de um pequeno universo, que pode também ter implicações em contextos mais amplos, já que se está tratando de “uma podridão do mundo". O mundo no Baixio é sórdido, e podese pensar que há, no filme, uma abordagem da própria condição humana, impregnada por uma moral subvertida.

\section{Sertão e litoral: uma possível renovação}

Pensar o sertão no cinema envolve também a dinâmica da relação desse espaço com outro que tradicionalmente é tratado como seu oposto: o litoral. Campo e cidade são, de forma recorrente, polos opostos a partir dos quais partem as questões de muitos filmes que abordam o sertão. Tomando um período recente do cinema nacional, a chamada Retomada, percebe-se de que maneira, em um filme como Central do Brasil (Walter Salles, 1998), a construção da narrativa gira em torno, essencialmente, da dicotomia entre campo e cidade. A partir do retrato que o filme faz desses dois mundos, pode-se depreender uma forma específica de elaborar o olhar sobre o sertão e de se conceber o Brasil. Oricchio observa que o sertão é, nesse filme, "o lugar da conciliação" (2003, p.138). É nesse espaço que se pode encontrar um Brasil profundo e livre de contaminações presentes no meio urbano.

A cidade é o lugar da violência, no qual uma pessoa pode ser friamente assassinada sob o olhar indiferente de todos. [...] O campo - o sertão, no caso - funciona como exata contrapartida e seria uma espécie de reserva moral da nação. É o lugar da pobreza digna, da solidariedade, dos valores profundos que se foram perdendo em outras partes, mas lá estão preservados, como num sítio arqueológico da ética nacional (ORICCHIO, 2003, p. 138). 
| Marcelo Dídimo Souza Vieira e Érico Oliveira de Araújo Lima

Walter Salles retomará a oposição entre sertão e litoral em um filme posterior, Abril despedaçado (2001). O litoral é aí promessa de uma vida diferente, de fuga da tradição marcada no sertão seco e opressor. A tradição do Cinema Novo é forte aqui, Sertão e Mar em oposição e, como observa Oricchio (2003), recorre-se constantemente à dicotomia entre esses dois espaços por meio da metáfora da encruzilhada, presente ao final do filme, quando o personagem Tonho (Rodrigo Santoro) escolhe o caminho que leva ao litoral.

Em Árido movie, logo durante a exibição dos créditos iniciais, há um movimento de câmera que sugere deslocamentos contidos na própria narrativa do filme. A câmera filma, de cima e deslocandose da direita para a esquerda, uma grande porção de água, o mar do litoral de Recife. O movimento marca mudança, transição e reunião de mundos distintos, o que, como se verá durante o filme, corresponde também ao próprio retorno do personagem Jonas a sua cidade natal, Rocha, motivado pelo assassinato de seu pai, Lázaro. Jonas vem de São Paulo, cidade que tanto simboliza

3. Os exemplos podem ser desde São Paulo S/A (1965, Luiz Sergio

Person) até o recente $\mathrm{O}$ invasor (Beto Brant, 2001). a grande metrópole caótica no cinema brasileiro ${ }^{3}$, e vai para o interior de Pernambuco, no sertão nordestino, retratado pelo diretor Lírio Ferreira como espaço da seca, do uso político e religioso da água, da tradição que prega a vingança em resposta a um crime cometido. Mas esse universo não está completamente isolado. Se, ao longo do filme, há o constante destaque para as diferenças entre Jonas e o mundo em que se vê inserido, não se pode ignorar como a condução da narrativa procura construir pontes, tentando pôr em contato litoral e sertão, ainda que para ressaltar, muitas vezes, pontos de choque.

A câmera percorre o mar de Recife ao som de música eletrônica, que retoma o tema trazido por Antonio Conselheiro em sua pregação messiânica e reapropriado por Glauber Rocha em seu pensamento estético e político, “o sertão virou mar, e o mar virou sertão". Imagem e som ressaltam como as fronteiras entre os dois mundos já não são tão claras. Porque se o sertão de Lírio Ferreira não se livrou de muitas práticas tradicionais, que devem ser continuadas por Jonas, cobrado por sua família, a estética do hibridismo proposta pelo filme conduz a uma justaposição de esferas distintas, não necessariamente integradas, mas sob 
mútua influência. Há celulares na pequena cidade de Rocha, há plantações de maconha e a promessa de aventuras que atraem os jovens amigos de Jonas para uma viagem de Recife ao interior do estado, há motocicletas e há a televisão, vista como o elemento de união mais geral, já que, por meio da imagem televisiva difundida em massa, Jonas, o homem do tempo no jornal produzido em São Paulo, pode ser visto diariamente pelos familiares.

Não há, nesse sentido, espaços isolados na abordagem de Lírio Ferreira. A conexão sertão-litoral é operada não só pela presença de personagens estrangeiros ao universo sertanejo: o já referido Jonas, seus três amigos e a videasta Soledad, mas pela própria postura do realizador, que trabalha um projeto estético de misturas, de aproximar referências culturais, o tradicional e o pop, o global e o local. Esse projeto já se anunciava na obra anterior de Ferreira, Baile perfumado (1997, em parceria com Paulo Caldas), que abordava a trajetória do cineasta Benjamin Abrahão e suas tentativas de registrar o grupo de Lampião, de forma a superar o conflito entre sertão e mar, marcante na tradição cinematográfica do Cinema Novo. Nagib (2006) observa na abordagem desse filme uma tentativa de criar uma continuidade entre sertão e mar, quase identificados entre si. Em Baile perfumado, encontram-se imagens de um sertão de fertilidade, com caatinga verde e muita água (de mar e também de rios) - nesse ponto, Árido movie vai por outro caminho, trazendo a falta de água e a seca como elementos constituintes do espaço do sertão.

\footnotetext{
Baile perfumado rompe o isolamento insular, indispensável à utopia glauberiana, para criar um clima que sugere uma confraternização globalizada, na qual um libanês é atraído por um cangaceiro e vice-versa [...] trata-se da abordagem do Brasil por meio de um instrumental internacionalizado, alheio ao purismo do projeto nacional que alimentou o início do cinema novo (NAGIB, 2006, p.53).
}

E a utopia glauberiana, a que a autora se refere, é marcante no projeto de Deus e o diabo na terra do sol (1964), conduzido sob a forte ideia de uma separação entre litoral e sertão. Os filmes iniciais 
| Marcelo Dídimo Souza Vieira e Érico Oliveira de Araújo Lima

de Glauber Rocha têm essa proposta clara de marcar o isolamento do sertão, concebido como um espaço representativo por excelência da situação de classes no Brasil. O Sertão seria aí microcosmo mais fechado e menos poroso a contaminações e misturas. Organizador de uma dinâmica própria, era espaço para que os realizadores se lançassem em busca de uma encenação nacional, um projeto para a emancipação política e a constituição de uma estética singular, com cores, sonoridades e temporalidades próprias.

Trata-se de um mundo ascético, sem nenhum resíduo de urbanidade, habitado por personagens que vivem em condições mínimas, com o fardamento típico de acampamento cangaceiro ou de vaqueiro pobre. O mundo do sertão tem uma dignidade e uma inteireza que dependem desse isolamento e dessa escassez. A falta de conforto como que sanciona tudo, até a violência. O espaço aí segrega, opõe valores. Sertão e litoral pertencem a universos distintos. Não têm nada a ver (XAVIER, 2000, p.114).

Essa proposta inicial do Cinema Novo, anterior ao golpe de 1964, assinalada pela demarcação clara de fronteiras, fundada na dualidade, no estabelecimento de polos, ocorre sob influência marcante da conjuntura política da época e do desejo dos cineastas em propor transformações políticas para o Brasil. Marcados pela esperança e propondo o sertão como alegoria do próprio país, esses filmes iniciais têm como elemento importante em sua construção o distanciamento do espaço representado. Orientam-se pela busca de uma "imagem realista do Nordeste seco e distante, do povo nordestino e sua condição de explorado, pela ausência do "habitat natural' dos próprios cineastas (jovens de classe média urbana)" (RAMOS, 1990, p. 348). As limitações desse projeto vão ser encontradas no próprio processo de realização, que se depara com contradições em sua base, com desafios de ordem estética, ética e política, na medida em que se percebe a impossibilidade de dirigirse a uma realidade já suposta e dada.

O olhar do cineasta urbano de classe média que olha para o sertão é fundamental, segundo Bernardet (2007), para que se 
possa alcançar um alto nível de abstração. O autor observa, por exemplo, que "Vidas secas [1963, Nelson Pereira dos Santos] é um filme urbano a respeito do campo, e sua validade vem de seu elevado grau de abstração" (BERNARDET, 2007, p. 88). Ainda que tenham o isolamento do espaço do sertanejo como pressuposto fundamental da construção fílmica, as obras da primeira fase do Cinema Novo não estão isentas de uma perspectiva urbana. É o olhar do cineasta que vai dar esse elemento de urbanidade e tornar a situação retratada no filme traduzível em termos gerais. Ainda sobre Vidas secas, diz Bernardet:

o filme deixa o sertão para colocar-se num nível mais geral. Fabiano [protagonista de Vidas secas] deixa praticamente de ser um homem particular, com problemas específicos, para tornar-se o homem brasileiro esmagado pela sociedade e colocado diante dos possíveis caminhos que lhe oferecem. Ele é tanto o sertanejo quanto o pequeno-burguês citadino, e talvez mais o segundo que o primeiro. [...] Fabiano não é apenas sertanejo, mas é qualquer um de nós que, no campo ou na cidade, estamos cerceados pelos poderes esmagadores da sociedade e vemos nossas possibilidades de realização e de progresso truncadas. [...] Para chegar a esse resultado, era necessário que o autor do filme fosse um homem da cidade (BERNARDET, 2007, p. 87).

O sertão dos primeiros filmes do Cinema Novo não está, portanto, completamente livre dos elementos de urbanidade. Pode-se pensar que, em termos da estrutura narrativa proposta pela obra, é efetivamente do sertão que se está falando. Mas quando se trata das implicações políticas e sociais que o filme pode trazer, é importante considerar também o olhar do cineasta que se propõe a falar do campo a partir de sua formação fundada no meio urbano. Quando os realizadores do Cinema Novo fazem sua autocrítica, no período posterior ao golpe de 1964, eles passam a dedicar-se mais diretamente ao espaço urbano e já não estruturam o pensamento estético segundo uma visão dualista do Brasil. Se antes se partia da eleição de um espaço que representaria o país por excelência, aos poucos o projeto cinemanovista passa a mudar o enfoque e o tom: 
| Marcelo Dídimo Souza Vieira e Érico Oliveira de Araújo Lima

sem a mesma esperança de mudança social de antes, os cineastas começam a se preocupar menos com a alteridade e a olhar para si mesmos, de forma mais clara que na fase anterior. "Aos reclamos de que o Cinema Novo só se ocupa de sertão e de favela, alguns filmes do período respondem com temas urbanos, de classe média: projetam na tela as mazelas da classe a que pertencem o realizador e o público" (XAVIER, 2001, p. 62).

E esse olhar vai caminhar em direção oposta a uma postura didática e conscientizadora. Xavier (2001) observa a aproximação dessa nova abordagem dos cineastas com a gestação do tropicalismo, que opta pela mistura de textos, linguagens e tradições, realizando o que o autor denomina de “invenções-traduções" (2001, p. 30).

\footnotetext{
A colagem tropicalista apresentaria um inventário das descontinuidades da história dos vencidos, cujo termo final seria a crise do sujeito no mundo contemporâneo, em especial a morte de dois sujeitos históricos: a do proletariado no seio da cultura de massas e a das nações no seio da globalização (XAVIER, 2001, p.31).
}

Esse olhar influenciado pelo tropicalismo deixou marcas na cultura brasileira de forma geral e tem ecos no projeto estético de Lírio Ferreira em Árido movie. É reflexo, sobretudo, dessa crise do sujeito de que fala Xavier. As invenções-traduções traçam configurações de paisagens híbridas e de personagens a meio caminho, perdidos no entre e na falta de referências. Já não estamos tanto em demarcações identitárias, mas em zonas de indeterminação, em conjuntos de possibilidades que tornam os caminhos de vida múltiplos e arriscados.

\section{Sexualidade e violência em tempos pós-utópicos}

Baixio das bestas traz para o que é tipicamente associado a um Brasil profundo toda essa construção de um mundo contaminado por um mal-estar social. Filmes do período da Retomada do cinema brasileiro revisitaram o universo do interior do Nordeste como lugar de pureza e conciliação dos problemas. Abril despedaçado 
(2001) e Central do Brasil (1998), ambos de Walter Salles, são casos exemplares da visão de um sertão distanciado do mundo urbano, um universo áspero no qual prevalecem os valores tradicionais, marcantes na vida dos sujeitos. Abril despedaçado, particularmente, insere-se numa discussão sobre a influência da tradição nas escolhas dos personagens, forçados a seguir a sina dos crimes familiares, da vingança pelo sangue. Dentro dessa mesma chave, mas com implicações diferentes, pois dentro de uma estética de misturas, Árido movie põe em choque a tradição do ambiente sertanejo e as referências urbanas. Já em Central do Brasil, cidade e campo relacionam-se como polos diferenciados pela pureza contida em cada um: ao contrário do que se vê em Baixio das bestas, é a cidade que se revela sórdida, enquanto o campo permite à personagem Dora encontrar-se com sua parte "sadia", nas palavras de Oricchio (2003) que retomamos aqui:

A cidade é o lugar da violência, no qual uma pessoa pode ser friamente assassinada sob o olhar indiferente de todos. [...] O campo - o sertão, no caso - funciona como exata contrapartida e seria uma espécie de reserva moral da nação. É o lugar da pobreza digna, da solidariedade, dos valores profundos que se foram perdendo em outras partes, mas lá estão preservados, como num sítio arqueológico da ética nacional (ORICCHIO, 2003, p. 138).

O que o diretor Cláudio Assis caracteriza como um mundo de decadência moral Walter Salles concebe como o lugar em que ainda reside a esperança para as vidas dos personagens. Assis não foca a dicotomia; são poucos os momentos em que se faz referência ao espaço urbano: sabe-se apenas que o personagem Cícero estuda em Recife e que o mestre do maracatu popular, Mário, vai à cidade, com seu grupo, tocar músicas e mostrar danças - aqui, pode-se ver um vestígio de uma concepção quanto à cultura popular e seus elementos de raízes ainda presentes no filme de Assis.

O foco, em Baixio das bestas, revela-se, assim, o próprio universo da comunidade retratada, com ênfase no sexo e na violência como processos que marcam a vida dos personagens. A sexualidade, 
| Marcelo Dídimo Souza Vieira e Érico Oliveira de Araújo Lima

naturalizada e viciada, constitui, biologicamente, os indivíduos. Jameson (2004), ao abordar a questão da utopia e dos impulsos utópicos, traz para o debate o que denomina "lições do vício e da sexualidade” (2004, p.174). Para o autor, a pós-modernidade reforça esses elementos como constituintes da própria natureza humana:

há algo a dizer da idéia de que as características que mencionei, o vício e a sexualidade, sejam os próprios emblemas da cultura humana como tal, os próprios suplementos que nos definem como coisa diferente dos meros animais: competitividade e paixão ou frenesi - não é isso que, paradoxalmente, forma a mente ou o próprio espírito, ao contrário do que é meramente físico e material? Nesse sentido, é muito humanamente compreensível que nos afastemos daquela utopia que Adorno descreve como uma comunidade de "bons animais". No entanto, também parece possível que um confronto genuíno com a utopia exija exatamente essas ansiedades e que, sem elas, nossa visão de futuros alternativos e transformações utópicas permaneça política e existencialmente inoperante, meras experiências de pensamento e jogos mentais sem nenhum compromisso visceral (JAMESON, 2004, p. 175-176).

Em Baixio das bestas, encaminha-se para o reconhecimento de que o interior nordestino já não é puro, muito menos estático. O filme enfatiza, no prólogo já referido, a marca do tempo, que a tudo engole, consciência de que o espaço retratado está inserido na história. O texto desse prólogo foi escrito por Carlos Pena Filho e usado em Menino de engenho (Walter Lima Jr, 1965), por uma introdução semelhante. Em Baixio, ele é lido por uma voz em off, com imagens em preto e branco de usinas em decadência: "Outrora aqui os engenhos recortavam a campina, veio o tempo e os engoliu. E ao tempo engoliu a usina. Um ou outro ainda há que diga, que o tempo vence no fim. Um dia ele engole a usina, como engole a ti e a mim". A relação entre os dois filmes é explícita, e o próprio Cláudio Assis faz referência, nos créditos finais de seu filme, à obra de Walter Lima Jr. 
Mas, se tanto o filme de Cláudio Assis como o de Lima Jr. organizam-se tendo as transformações na indústria canavieira nordestina como pano de fundo, as abordagens são bem diferentes. Menino de engenho centra-se no drama familiar e, sobretudo, no olhar da criança diante da ruína do mundo: Bernardet (2007), ao tratar do marginalismo nos filmes do Cinema Novo, coloca a obra como exemplo da tematização da criança como marginalizada. Se em Baixio das bestas também há marginalização, é principalmente da mulher, do feminino violentado, na relação de poder com os homens. As prostitutas encontram-se completamente à margem, reunidas numa casa à parte e sonhando com vida nova. São, para os homens, objetos que podem ter seus corpos invadidos e violentados conforme a vontade do macho. É, sobretudo, dentro de uma lógica de poder repressor que sexo e violência são articulados no espaço degradado do interior do Nordeste.

Corisco e Dadá (Rosemberg Cariry, 1996) trazia também essa violência contra a mulher. Nos primeiros contatos entre Dadá e Corisco, uma "violentação", a imposição da vontade do homem sobre os desejos da mulher: é só depois que esses corpos estarão unidos em pé de igualdade, no comando do cangaço como resistência. Cariry filia-se mais a uma estética da violência no estilo cinemanovista, ao deslocar Dadá, a mulher violentada, junto ao cangaceiro de conotações revolucionárias: ela é retirada da condição de alienação e passividade e se integra à ação violenta contra o sistema, ao lado dos homens.

Em Latitude zero (Toni Venturi, 2000), a mulher assumia sua história, num Brasil profundo e vazio, sem ninguém e isolado do restante do mundo, como já observou Nagib (2006). No filme, a personagem feminina está só e resiste "à ação opressora dos machos passados e presentes" (NAGIB, 2006, p. 88). Na paisagem desértica, a protagonista, grávida, dirige um bar sem fregueses e simboliza uma resistência ao tempo e às ruínas representadas por um garimpo abandonado. Através de um "mergulho nas entranhas femininas", o filme de Venturi afirma o "crepúsculo do macho" e um "país das amazonas" (2006, p. 89). 
| Marcelo Dídimo Souza Vieira e Érico Oliveira de Araújo Lima

A afirmação da mulher acontece, também, em O céu de Suely (Karim Aïnouz, 2005), filme que segue também pelo caminho da rejeição de uma abordagem da pureza do sertão. Na cidade de Iguatu, convivem diferentes estágios de desenvolvimento arcaico e moderno são postos em contato. A protagonista Hermila, desejando liberdade diante de um espaço opressor, vai buscar construir o próprio caminho, através de uma subversão moral, diante dos costumes da cidade: ela resolve rifar o corpo. A partir da troca de uma noite no paraíso, ela pretende reunir o dinheiro necessário a uma viagem para o lugar mais distante possível. O sexo entra aí como um meio de libertação, numa inserção da lógica de negociação do corpo. Hermila tem uma amiga prostituta, que a instrui sobre o jogo existente na lógica de lucrar com o sexo. Em O céu de Suely, as mulheres parecem tomar a frente, sabem bem o que querem e não se deixam subordinar pelos homens, postos como coadjuvantes. Se há opressão, o filme de Karim Aïnouz aponta reações das mulheres, formas de resistência no espaço micro, numa formulação de utopias individuais.

O que se sobrepõe em Baixio das bestas é a situação de impossibilidade de resistir, como se os personagens estivessem em becos sem saída. Mesmo quando Auxiliadora livra-se de seu avô, o destino dela é assumir a posição de prostituta, consumando um destino que já se anunciava: reafirmada a inevitabilidade dos acontecimentos, resta pouco espaço para a resistência e a afirmação dos sujeitos.

Pode-se especular se a falta de perspectivas no conteúdo relacionase também a uma postura estética de reiteração das condições do mundo. Ao longo dos anos 1960 e 1970, a abordagem formal dos diretores transforma-se conforme a desilusão ganha ênfase. Como destaca Xavier (1993), as alegorias transformam-se em direção à perda de certezas e à diluição da teleologia da história, a crença num fim redentor para a sociedade, que alcançaria o mar, seguindo o caminho aberto por Manuel em Deus e o diabo na terra do sol. A estética da violência, encontrada nos filmes de Glauber Rocha, muda, progressivamente, de sentido e de relação com os rumos do país. A partir de Terra em transe, viria a "consciência abismal 
de fracasso", em substituição ao "télos salvacional" (XAVIER, 2007, p. 196). Em O dragão da maldade contra o santo guerreiro (Glauber Rocha, 1969), tem-se o reconhecimento da "dificuldade em reconciliar a utopia revolucionária e a dinâmica efetiva do país real" (XAVIER, 1993, p. 186). O retorno do cangaceiro, Coirana, e do intermediário, Antonio das Mortes, em nova encenação da violência, já ocorre segundo novo olhar, que reconhece as contradições e afirma as incertezas. É, sobretudo, em torno de uma crítica à modernização conservadora, implementada durante o regime militar, que a narrativa de $\mathrm{O}$ dragão da maldade estruturase: o moderno não correspondeu aos anseios de transformação.

O filme desconfia, sem dúvida, da modernização e lhe endereça a sua condenação moral. Mas sabe da sua efetividade, do quanto ela negou a antiga teleologia do sertão/mar e exige a sua inclusão no diagnóstico geral, aqui formulado de modo oblíquo. Neste sentido, Glauber tem uma forma muito peculiar de trabalhar a articulação arcaico/moderno, inversão da colagem tropicalista. Nesta, o moderno expõe o disparate do arcaico, produzindo a incorporação paródica dos clichês da cultura dos avôs. Em O dragão da maldade, é a dignidade do arcaico que desautoriza o "moderno espúrio", produzindo a crítica do presente como um avanço cheio de equívocos, efetivo porém viciado. A alegoria de Glauber é a expressão do descompasso entre a teleologia da história, que se queria, e o fluxo do tempo que se impôs. O real, modernizante, é ilegítimo; o passado é força simbólica, fonte da Revolução, mas sua eficácia está comprometida porque não pode agir sem se contaminar com o presente, esta engrenagem a reduzir o sagrado a simulacro (XAVIER, 1993, p. 186, grifo do autor).

Tomando, mais uma vez, o prólogo de Baixio das bestas e sua reflexão sobre o tempo, pode-se identificar uma similaridade de perspectivas em relação a $\mathrm{O}$ dragão da maldade: o moderno instaura uma condenação moral, uma desilusão com as possibilidades do país. Ao reafirmar a degradação, Cláudio Assis alinha-se a um certo fim das utopias, que já se encaminhava na transição dos anos 1960 para 1970, mas é reafirmado a partir da globalização e da 
| Marcelo Dídimo Souza Vieira e Érico Oliveira de Araújo Lima

constituição de um sistema de produção hegemônico. A Assis, resta exacerbar o caráter degradante da constituição dos seres e afirmar a violência como dado do mundo. Tudo isso com uma estética de plasticidade, fotografia bem pensada, organização bem estudada dos planos. Sobre seu modo de filmar, o diretor já afirmava, em referência a Amarelo manga:

\title{
4. Entrevista de Cláudio Assis à revista Contracampo, edição 52 .
}

A câmera vai para todo o canto, tem de estar tudo cenografado, se não fico escravo de um limite. Amarelo manga é um filme difícil. Trata da miséria humana. Se não buscarmos uma elegância no movimento de câmera, no enquadramento, no desenho das cenas, fica um negócio feio e podre. Uma das minhas preocupações era fazer com que as coisas não ficassem restritas. A gente se preocupou ao máximo para haver prazer em se ver o filme. Isso interfere em todo o processo. É como o americano faz, mas do nosso jeito, filmando nosso povo (CONTRACAMPO, [s. d.] $)^{4}$.

Assis revela, a todo o momento, uma preocupação em tratar a realidade brasileira com uma estética própria que não reproduza os códigos do cinema hegemônico, mas que afirme um novo jeito de filmar, novas formas de ver. Nas intenções, expressas na entrevista, o diretor revela-se político, numa rejeição ao que Bernardet (1991) já chamou de mimetismo.

\begin{abstract}
O mimetismo consistiria no seguinte: já que o público está vinculado ao espetáculo estrangeiro, produzir filmes brasileiros que satisfaçam no espectador os gostos e as expectativas criadas pelo cinema estrangeiro. Trata-se de reproduzir no Brasil o produto importado (BERNARDET, 1991, p. 70).
\end{abstract}

Tratar a violência de uma forma própria é rejeitar as convenções formais de Hollywood: nas palavras de Assis, "Nossas histórias precisam ser contadas de outra maneira. Somos outro povo. Não temos de imitar para ser aceitos". Mas a resistência contra uma estética dominante, que ressoa a postura cinemanovista, postulada 
5. Ver discussão mais ampla no capítulo: "A alegoria em nova chave: a transgressão do cinema experimental", em XAVIER, I. Alegorias do subdesenvolvimento. São Paulo: Brasiliense, 1993. por Glauber, de uma estética da fome, distancia-se da abordagem dos filmes dos anos 1960, justamente pela opção por construções imagéticas belas e harmônicas, uma elegância no movimento de câmera. Tenta-se evitar, para retomar as palavras acima de Assis, que fique "um negócio feio e podre", numa intenção de tornar possível "haver prazer em se ver o filme". Essas preocupações do diretor, presentes em Amarelo manga, repetem-se em Baixio das bestas, na colocação dos atores em cena, na iluminação dos espaços, na fluidez da câmera: a fotografia de Walter Carvalho, especialmente, colabora para dar à "podridão do mundo" um tratamento formal estilizado.

A abordagem da violência e do sexo em Cláudio Assis não corresponde, portanto, a uma violência formal, de precariedade, desarticulação e disjunção, tão a gosto da estética da fome e, sobretudo, da produção mais radicalizada do Cinema Marginal, que viria a exprimir, pela estética, um desencantamento com o mundo 5 . Baixio das bestas traz temas e personagens marginalizados de forma bela e poética: "a gente tem uma violência nossa, cotidiana, dentro da nossa própria casa, que é tão violenta quanto filmes de Hollywood. Queria fazer um filme sobre essas pequenas violências, que fosse poético e violento ao mesmo tempo", diz Assis. O diretor aponta sua câmera para um mundo caótico, mas impõe uma ordem formal a esses caos, instiga o prazer diante da imagem que contém, internamente, a natureza degradante do ser humano. O caminho aproxima-se, nesse sentido, da despolitização criticada por Xavier (2000) acima, numa opção de condenação moral que não sugere uma redisposição dos lugares dos sujeitos e dos possíveis da imagem. Referindo-se a filmes dos anos 1960 que traziam os temas do sexo e da abjeção, Bernardet (2007) já alertava:

Apresentando ao mundo (à burguesia) uma imagem degradada dele mesmo, pensa-se condená-lo, rejeitálo. Em realidade, essa degradação revela mais autodesprezo do que vontade de atuar no mundo. A ação dessa atitude sobre o público está limitada, pois ele aceita não sem prazer a imagem de um mundo aviltado (BERNARDET, 2007, p. 129). 
Baixio das bestas constrói um olhar próximo ao que Bernardet chama de "autodesprezo", criando imagens incapazes de formular questões sobre o mundo que retratam. Ainda que as intenções de Assis tenham caráter político, a partir da defesa de formas próprias de filmar, a estética concebida pelo diretor como sua, associada à fotografia de Walter Carvalho, faz da violência algo belo e torna digerível a convulsão social: a ênfase no prazer em ver o filme e contemplar a degradação faz de Baixio das bestas um filme esvaziado por dentro, preso às suas próprias armadilhas formais. Longe das utopias dos anos 1960, o filme retrata um mundo para o qual não há esperança, marcado pela alienação contemporânea de jovens de classe média, por uma sociedade patriarcal e pelas incertezas quanto ao futuro.

\section{Temporalidades das utopias}

A compreensão da abordagem dada pelo diretor Lírio Ferreira, em Árido movie, a temas como a falta de água no sertão, a indústria da seca e o misticismo popular requer uma reflexão sobre a mudança de enfoque ocorrida no cinema brasileiro contemporâneo, sobretudo colocando em comparação a visão que o cineasta tem de si nos anos 1990 e a autoimagem de diretores durante o Cinema Novo.

Havia a crença por parte da geração cinemanovista num mandato e no papel político do cineasta. Acreditava-se numa vocação emancipadora e na construção de um discurso preocupado com a coletividade e com categorias mais gerais ligadas ao subdesenvolvimento, à identidade nacional e a uma linguagem cinematográfica de resposta ao colonizador e de "desalienação" do colonizado. "O cineasta se via como portador de um mandato que, no caso brasileiro, se concebia como vindo do próprio tecido da nação, suposto muito mais coeso e já constituído do que, em seguida, a realidade veio mostrar" (XAVIER, 2000, p. 99).

Postura diferente do que se verificou no ciclo de Recife, durante os anos 1920, quando se incorporava a linguagem clássica trabalhada em Hollywood, para tratar o novo de forma conservadora. Esse ciclo regional foi marcado pela produção colaborativa e 
filmava os avanços urbanos na cidade com fascínio. Dava-se num clima de oposição entre a ânsia pelo novo e o modelo tradicional da região, controlada por oligarquias. Era uma tentativa de conciliar as mudanças da modernidade e a permanência da tradição (ARAÚJO, 2006). No filme A filha do advogado (Jota Soares, 1926), por exemplo, misturavam-se o "fascínio material pelo atraente mundo de consumo da elite" e a "condenação moral, diante da dissipação dos valores mais tradicionais" (2006, p. 121). Na abordagem dos filmes do ciclo, "as mudanças são incorporadas e submetidas aos valores tradicionais - e nessa incorporação elas perdem seu eventual poder transgressivo, de efetiva mudança social, econômica, de mentalidade. Resta uma aparência de mudança" (2006, p. 122).

Já a postura estética nos anos 1960 estava ligada ao clima de efervescência política e cultural de proposição de novos caminhos para o país e de liberação nacional. A tônica dos debates em torno da cultura popular, da alienação, do processo histórico e da revolução é marcante para o encaminhamento de pautas mais engajadas na produção cinematográfica. Dados os desafios de construir um discurso coletivo a partir da complexidade da sociedade brasileira, os cineastas expressam nas obras as contradições dos próprios posicionamentos e uma constante mudança de olhar para a noção de povo e para os problemas estruturais do país. A relação contraditória com o popular é incorporada, por exemplo, por Glauber Rocha em dois filmes do início de sua carreira: Barravento (1962) e Deus e o diabo na terra do sol, que "internalizam o duplo movimento de valorização-desvalorização do popular" (XAVIER, 2007, p. 191). Partindo, ao mesmo tempo, de uma crítica da cultura popular como alienante e da valorização das manifestações do povo como formas de resistência, os filmes uniam a ideia de que era preciso conscientizar o povo quanto à postura de uma busca desse povo. "Marcados pela postura de conscientização própria aos projetos da época, os dois filmes manifestam algo além do autoritarismo populista, pois a boa arte não se reduz a um mero duplo da ideologia" (2007, p. 191).

Os caminhos da revolução na história são fragmentados, não são lineares, e a estética da violência defendida por Glauber Rocha 
| Marcelo Dídimo Souza Vieira e Érico Oliveira de Araújo Lima

procura mostrar a luta do oprimido no presente inspirada pelos mitos do passado. É uma tentativa de "trabalhar a relação entre fome, religião e violência $[\ldots]$ e legitimar a resposta do oprimido, evidenciando a presença, no Brasil, de uma tradição de rebeldia que negaria a versão oficial da índole pacífica do povo" (XAVIER, 2001, p. 19). Em Deus e o diabo, revisitada a história do sertão, a memória e o mito passam a ser pontos de partida para a transformação e, ao mesmo tempo, devem ser reavaliados.

[O discurso] polemiza com a tradição e parte dos mitos para inseri-los num processo de transformação, denunciando seus limites, sua humanidade. A recapitulação de messianismo e cangaço tem em comum com a memória coletiva esse movimento de recuperar o passado e seus heróis, para impedir seu desgaste e morte pelo tempo, para ressaltar sua dignidade [...] Deus e o diabo projeta esses mesmos heróis numa temporalidade marcada pelo movimento incontido, pelas necessidades históricas que decretam a morte de uns e outros como essencial para o progresso dos homens e para a realização do princípio de justiça (XAVIER, 2007, p. 138).

E invocar a memória, atitude comum no cinema político do Terceiro Mundo, é muito mais do que simplesmente recordar um passado ou conceber uma formação definida de um povo já existente. Isso porque um novo elemento se faz presente no discurso: o privado, o eu e sua relação com o coletivo e com o político. Porque a memória, diz Deleuze (2007), é “a estranha faculdade que põe em contato imediato o fora e o dentro, o assunto do povo e o assunto privado, o povo que falta e o eu que se ausenta, uma membrana, um duplo devir" (2007, p. 263). É no nível da fabulação e da lenda que será possível alcançar o coletivo a partir dos personagens individuais, postos como "intercessores", o que Glauber Rocha já fazia com Antônio das Mortes em Deus e o diabo.

Resta ao autor a possibilidade de se dar "intercessores", isto é, de tomar personagens reais e não fictícias, mas colocando-as em condição de ficcionar por si próprias, de "criar lendas", "fabular". O autor dá um passo no 
rumo de seus personagens, mas as personagens dão um passo rumo ao autor: duplo devir. A fabulação não é um mito impessoal, mas também não é ficção pessoal: é uma palavra em ato, um ato de fala pelo qual a personagem nunca pára de atravessar a fronteira que separa seu assunto privado da política, e produz, ela própria, enunciados coletivos (DELEUZE, 2007, p. 264, grifo do autor).

A constituição de um cinema moderno no Brasil durante a geração do Cinema Novo marcava-se pela transição de concepções sobre o povo, progressivamente compreendido de forma fragmentada, um povo que precisava ainda ser inventado. As posturas na relação com o país são revestidas de maiores nuances, para abrir-se a incertezas. $\mathrm{O}$ projeto cinemanovista se fende como o que se relança e se joga em imponderabilidades. Passa-se a compreender que o povo falta, ele não está dado e pronto para que o cineasta dirija-se a sujeitos já supostos e os represente na tela.

não havia povo, mas sempre vários povos, uma infinidade de povos, que faltava unir, ou que não se devia unir, para que o problema mudasse. É por aí que o cinema do Terceiro Mundo é um cinema de minorias, pois o povo só existe enquanto minoria, por isso ele falta. É nas minorias que o assunto privado é, imediatamente, político. [...] o cinema político moderno constitui-se com base nessa fragmentação, nesse estilhaçamento (DELEUZE, 2007, p. 262).

Havia, nesse sentido, um movimento de fugir de uma homogeneização do país. Ainda que a busca por um discurso do coletivo permanecesse, verificava-se mais e mais uma compreensão da complexa realidade brasileira, e a dimensão utópica contida no desejo por mudanças sociais vai cedendo lugar ao desencanto. As alegorias da esperança são substituídas por aquelas do desencanto, porque o cineasta perdeu a "inocência”, "perdeu as certezas típicas daquela época em que a cinefilia continha, em si mesma, uma forte dimensão utópica, de projeção para um futuro melhor da arte e da sociedade" (XAVIER, 2001, p. 43). O cineasta passa a se reconhecer, destaca Xavier, como parte da mídia que tematiza, já 
| Marcelo Dídimo Souza Vieira e Érico Oliveira de Araújo Lima

que as próprias condições de produção exigem que o diretor recorra a diferentes canais de captação de recursos: "a tônica, desde 1993, tem sido o pragmatismo" (2001, p. 42), e já não existem mais os debates e o clima cultural na base da produção dos filmes. Xavier ainda aponta para a falta de uma relação estética com o passado, sem que, no entanto, tenham acontecido rupturas. A autoimagem do cineasta brasileiro contemporâneo sofreu, nesse sentido, um deslocamento: ele "já não traduz em seus filmes, com raras exceções, a mesma convicção de ser um porta-voz da coletividade" (XAVIER, 2000, p. 99). “Ao contrário dos anos 60, quando o cinema se apressava em interligar ser social, economia e caráter (colocando no centro a questão da ideologia), a vontade agora é explorar mais os sujeitos no que têm de singular" (2000, p. 104).

Nagib (2006) observa que, se há um diálogo do cinema brasileiro atual com a tradição que o antecede, isso se dá muito mais sob uma perspectiva nostálgica. Não há a criação de um projeto político dentro das estéticas do cinema contemporâneo.

\footnotetext{
Num mundo globalizado, pós-utópico e desprovido de propostas políticas, em que projetos nacionais há muito deram lugar a relações e estéticas transnacionais, a nova utopia brasileira necessariamente significou olhar para trás e reavaliar propostas passadas centradas na nação. [...] Nostalgia, homenagem, citação e desejo de continuidade histórica foram os modos encontrados para a expressão do mar utópico que reemergiu com todo seu poder simbólico no novo cinema brasileiro (NAGIB, 2006, p. 25-26).
}

Se o mar utópico era, em Glauber Rocha, a visão do paraíso, a certeza da transformação, o mar de Lírio Ferreira não traz possibilidades de mudança. Na verdade, é da inevitabilidade da permanência que Árido movie trata: mais do que um filme pós-utópico, trata-se de uma obra antiutópica, em que as condições são dadas e não há nada que se possa fazer. A todo o momento, seja pela voz over de Jonas, seja no telejornal durante a previsão do tempo, uma frase se repete: "Não há previsões de mudanças" - mais do que do clima, se está falando das condições estruturais da sociedade no sertão nordestino e do estado de espírito do próprio Jonas. 
Na sequência já referida acima, em que os créditos aparecem e a câmera filma de cima o mar de Recife, a profecia de Antônio Conselheiro é cantada, "o sertão virou mar, e o mar virou sertão". Além de mostrar o fim das fronteiras entre sertão e litoral, pode-se agora tratar de outra implicação contida na frase. A perspectiva de Conselheiro e de Glauber Rocha partia de uma sentença construída no futuro, "o sertão vai virar mar, e o mar vai virar sertão". Era antes uma profecia, um indicativo de futuro, quando a sociedade se transformaria. Em Árido movie, o sertão virou mar, e o mar virou sertão, "as águas baixaram", de modo que as condições políticas e sociais vistas no filme não devem sofrer alterações, porque a mudança está situada no passado, as lutas não estão no presente.

A família de Jonas simboliza esse conservadorismo e a busca por garantir que nada mude. Uma família que tem como executores da violência opressora Marcio Greyck e Salustiano, a força e a inteligência, como é dito ao final. Eles têm seus jagunços, que já não andam mais em cavalos, mas em motocicletas, bem armados. Cuidam não mais de plantações de algodão, mas de plantações de maconha e do imbricado controle político da água, negócio que tem implicações no âmbito nacional, como é anunciado em notícia no telejornal, sobre "a fraude da irrigação" por deputados de Brasília. Se os homens executam o poder opressor, é uma mulher que se encarrega de dar as ordens e exercer uma liderança ideológica, fundada na tradição familiar e nos valores religiosos. A avó de Jonas, Dona Carmo, é a figura que conserva os valores da família, a ordem estabelecida.

O foco acaba sendo na ação dos opressores em conservar as estruturas. Aos oprimidos, resta o conformismo ou a fuga. Quando a ordem se quebra, no início do filme, e o índio Jurandir mata um representante da família oligárquica, a Lázaro, para "defender a honra" de sua irmã, Wedja, só lhe resta se esconder. Ao longo do filme, o que se destaca é a tentativa de restabelecer a ordem, a obrigação de Jonas em vingar o pai e a constante busca dos jagunços por Jurandir. Essa lógica é exatamente a inversa do que se tinha em Deus e o diabo na terra do sol. Se no início do filme o vaqueiro Manuel mata o patrão, coronel Morais, a partir daí o que se tem é o 
| Marcelo Dídimo Souza Vieira e Érico Oliveira de Araújo Lima

foco no percurso de Manuel pela libertação revolucionária, primeiro no misticismo, depois no cangaço e, posteriormente, libertado dos dois, em direção ao mar, à revolução livre de amarras. Nesse percurso, a preocupação não está no nível das forças conservadoras, como em Árido movie, mas nas forças revolucionárias.

O confronto entre Jurandir e Lázaro tem um caráter político, pensado em torno de uma distribuição de lugares e de funções no mundo. E a frase dita por Lázaro é essencial para compreender a dimensão que ele e sua família dão às ocupações sociais na região: "Cada uma! Tu és um merda! Tu faz o teu serviço e eu faço o meu! É assim que o mundo gira”. A resposta de Jurandir é o tiro que sai de sua arma. Mais tarde, Zé Elétrico, índio que esconde Jurandir, vai dizer: "Bala não respeita ninguém". A possibilidade de quebrar a ordem deu-se pela violência, mas o desencadeamento de uma reação só fica no nível da bala, já que ao assassinato de Lázaro não se segue um processo transformador, mas a recomposição do status quo. Após a morte de Lázaro, a câmera filma a televisão, na qual aparece Jonas. Na previsão do tempo no telejornal de São Paulo, com o mapa do Nordeste ao fundo, ele diz em tom tranquilo e didático: "Não há previsões de mudanças".

O próprio Zé Elétrico revela-se consciente da situação histórica de exploração, mas imobilizado pelo conformismo. O personagem profere um discurso sobre a trajetória de opressão dos índios, o controle da água pelos detentores do poder e a sua experiência pessoal com a exploração. Mas concebe as condições como inevitáveis, não se torna sujeito de sua história. Ao final, morto Jurandir, Zé Elétrico é cobrado por ter escondido o amigo. Como compensação pelo desvio, terá que fazer um serviço para Marcio Greyck, viajar e vender maconha.

O líder místico Meu Velho é ainda outro elemento que retoma questões políticas da tradição cinematográfica brasileira. Ele é agora, entretanto, uma figura integrada à lógica de poder local, que dialoga com a família de Dona Carmo e que prefere fazer sua "poética das águas" apenas no nível espiritual como curandeiro. Consciente de sua autoimagem, ele sabe bem como se portar diante da câmera da videasta Soledad e explicar sua filosofia de um "representante direto de Deus". 
Esvaziada a dimensão utópica, ganha destaque a perspectiva do transe, mas em tônica diferente da que tínhamos em Glauber Rocha. Lá era o transe dos sentidos que deslocava a experiência e buscava desinstalar o pensamento de seguranças e de manutenções da ordem. Ao Jonas de Árido movie, no entanto, restam um chá alucinógeno preparado por Zé Elétrico e a confusão mental ao final do filme. Aos seus amigos Bob, Falcão e Verinha, resta ficar à margem dos problemas enfrentados pelo protagonista. Eles vivem aventuras num sertão reduzido ao lugar da "plantação dos sonhos", uma plantação de maconha. Falcão já anuncia, antes da partida rumo a Rocha, sua visão do sertão como lugar exótico e de aventuras: “Sertão é massa, né, velho?”. É a expressão da alienação contemporânea e do esvaziamento da ação política. Os três jovens dançam, conversam e fumam; se encantam com o sertão "massa", deslumbrados com o transe da viagem. São como a personagem Marina, de O invasor (Beto Brant, 2001), que não vive no sertão, mas na metrópole São Paulo: "vivendo só de diversão e movida a drogas e baladas, num tempo desprovido de propostas políticas, é talvez a principal revelação do filme como sintoma do capitalismo tardio" (NAGIB, 2006, p. 177).

\section{Considerações finais}

"O sertão virou mar, e o mar virou sertão": dessa ideia parte Árido movie. Na sequência, Lírio Ferreira promove a união entre sertão e litoral e inverte a perspectiva revolucionária de Glauber Rocha para uma ideia de permanência. Os eventos em Árido movie são marcados pela continuidade das condições dadas previamente, e os vislumbres de modernidade que são lançados ao longo do filme estão no nível da inovação tecnológica e do fim de fronteiras entre dois mundos. Mas a estrutura social básica não muda: se os jagunços comandados pela família oligárquica agora têm motocicletas e não cavalos, a função repressora permanece a mesma. $\mathrm{O}$ toque entre sertão e litoral fica apenas na superfície, não tem implicações políticas mais gerais.

O efeito dessa mistura se coloca também no dilema de Jonas, personagem que, convivendo com dois universos distintos, opera 
| Marcelo Dídimo Souza Vieira e Érico Oliveira de Araújo Lima

o encontro das realidades. Sujeito a múltiplas influências, ele tem uma identidade difusa, não se sente em casa, é um estrangeiro. Ao confrontar-se com a tradição, tenta resistir, questiona suas raízes e o continuísmo do costume da vingança. Em Jonas, há vislumbres de uma atitude política no âmbito individual, uma resistência, um questionamento das condições postas. A postura dele acaba, entretanto, tão confusa quanto suas sensações. Sem saber o que fazer, ele também não sabe marcar uma posição clara, acaba passando por sua pequena cidade natal de forma inerte. O chá de Zé Elétrico gera o transe em Jonas, retira-o de um eixo claro e acaba encaminhando-o para o inevitável. A opção de Lírio Ferreira por um final aberto é uma opção de se retirar daquele mundo, escapar de escolhas, porque, assim como Jonas, ele não marca posição, apresenta-se de forma difusa.

Árido movie não foge de temas caros à tradição cinematográfica brasileira. Volta-se para o sertão, em diálogo tanto com o Cinema Novo quanto com filmes contemporâneos. Da geração cinemanovista, retira temas, do cinema contemporâneo, continua a abordagem já distante da ideia de engajamentos macropolíticos. É um filme inserido na lógica da globalização, com seu hibridismo estético e seu esvaziamento quanto a perspectivas de mudanças.

O Nordeste de Cláudio Assis está contaminado por uma “podridão do mundo", e a imagem que traz essa podridão é limpa, suave, fluida. Baixio das bestas concentra-se na decadência moral de um mundo e impregna-se de uma desilusão com os rumos da sociedade. A patologia social é denunciada, afirmada e reiterada pela estética do diretor, mas não há a preocupação em propor o reordenamento dos corpos postos em choque. As partes do universo abjeto são inventariadas, mas não são deslocadas: o filme contentase em olhar de forma distanciada para esse mundo e, mais ainda, busca prazer estético no ato de captar a abjeção.

A condenação moral tem como pano de fundo estruturas sociais em ruínas, opressão nas relações interpessoais e violência naturalizada pelo próprio espaço repressor. Homem e sociedade estão interligados - não há, portanto, uma completa segregação entre estrutura e mentalidades, dado que há uma mínima preocupação 
em contextualizar. A sexualidade é envolta pelo estigma do vício, os corpos femininos estão capturados pelos desejos dos homens, e o Baixio afigura-se como uma região distante de purezas.

Forma diferenciada de trazer o universo nordestino, o filme revela uma postura próxima ao que Assis reivindica como uma oposição ao cinema de Hollywood. Ainda assim, é preciso questionar em que medida a afirmação de uma forma própria ressoa em Baixio das bestas como uma proposição de um cinema que fala e que é capaz de propor questões ao universo em que se insere. Assis é político na reivindicação de um olhar próprio e na elaboração de um painel múltiplo de sujeitos, mas o olhar formulado parece ainda carente de uma potência de deslocar o que está posto. 


\section{Referências}

ARAÚJO, L. C. de. "Melodrama e vida moderna: o Recife dos anos 1920 em A Filha do Advogado". Cadernos de Pós-Graduação da Unicamp, v. 3, 2006.

BERNARDET, J-C. Brasil em tempo de cinema: ensaios sobre o cinema brasileiro. São Paulo: Companhia das Letras, 2007.

Cinema brasileiro: propostas para uma história. Rio de Janeiro: Paz e Terra, 1991.

CONTRACAMPO. "Entrevista com Claudio Assis". Edição 52. Disponível em: <http://www.contracampo.com.br/52/ entrevistaclaudioassis.htm>. Acesso em: 21 jun. 2012.

DELEUZE, G. A imagem-tempo (Cinema 2). São Paulo: Brasiliense, 2007.

. "Controle e devir". In: DELEUZE, G. Conversações (1972-1990). São Paulo: Ed. 34, 1992.

EDUARDO, C. "A 'fenômeno-patologia' do pequeno poder". Revista Cinética, 2007. Disponível em: $<$ http://www.revistacinetica. com.br/baixiocleber.htm>. Acesso em: 21 jun. 2012.

GOMES, P. E. S. Cinema: trajetória no subdesenvolvimento. São Paulo: Paz e Terra, 1996.

JAMESON, F. “A política da utopia”. Versão em português de “The Politics of Utopia”, New Left Review 25, January-February 2004. Disponível em: <http://nlrl.newleftreview.org/article/download_ pdf?language $=$ pt\&id=2489>. Acesso em: 21 jun. 2012.

NAGIB, L. A utopia no cinema brasileiro: matrizes, nostalgias, distopias. São Paulo: Cosac Naify, 2006.

ORICCHIO, L. Z. Cinema de novo: um balanço crítico da retomada. São Paulo: Estação Liberdade, 2003.

RAMOS, F. (Org.). História do cinema brasileiro. São Paulo: Art Editora, 1990.

XAVIER, I. Alegorias do subdesenvolvimento. São Paulo: Brasiliense, 1993. 
“O cinema brasileiro nos anos 90" (entrevista). Revista Praga: estudos marxistas, São Paulo, n. 9, junho de 2000, p. 97-138. O cinema brasileiro moderno. São Paulo: Paz e Terra, 2001.

Sertão mar: Glauber Rocha e a estética da fome. São Paulo: Cosac Naify, 2007. 